\title{
Miranda
}

Revue pluridisciplinaire du monde anglophone /

Multidisciplinary peer-reviewed journal on the English-

speaking world

$21 \mid 2020$

Modernism and the Obscene

\section{Staging the Obscene in A Glastonbury Romance (1932) by John Cowper Powys}

\section{Florence Marie}

\section{OpenEdition}

\section{Journals}

\section{Electronic version}

URL: http://journals.openedition.org/miranda/27847

DOI: 10.4000/miranda.27847

ISSN: 2108-6559

Publisher

Université Toulouse - Jean Jaurès

\section{Electronic reference}

Florence Marie, "Staging the Obscene in A Glastonbury Romance (1932) by John Cowper Powys",

Miranda [Online], 21 | 2020, Online since 09 October 2020, connection on 16 February 2021. URL:

http://journals.openedition.org/miranda/27847 ; DOI: https://doi.org/10.4000/miranda.27847

This text was automatically generated on 16 February 2021.

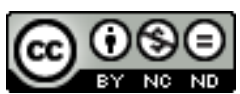

Miranda is licensed under a Creative Commons Attribution-NonCommercial-NoDerivatives 4.0 International License. 


\title{
Staging the Obscene in A Glastonbury Romance (1932) by John Cowper Powys
}

\author{
Florence Marie
}

1 'Nobody quite knows what the word 'obscene' itself means, or what it is intended to mean: but gradually all the old words that belong to the body below the navel have come to be judged as obscene. Obscene means today that the policeman thinks he has a right to arrest you, nothing else" (Lawrence 625). As made clear by D. H. Lawrence in 1929, there existed no definition of the term "obscenity" under English statute law. Nevertheless the idea that "fiction has the power to corrupt and offend in its cultural significance" (Potter 2013b, 10) and as a consequence that censorship was advisable was still very much in the foreground in the 1920s. This did not prevent some modernist novelists from dramatizing issues of sexuality more blatantly: "writers who saw themselves at the forefront of literary developments became more experimentally obscene in their writing about sex, excrement, and physical corruption" (Potter 2013b, 71). Thus some works were banned in the United Kingdom-for example Ulysses in 1923 -while others, such as Lady Chatterley's Lover (1928), were not even published there in the first place. Such was not the case of John Cowper Powys's works although he had been referred to by the American Moral Prosecutor in 1921 as "Powys the English Degenerate" (Peltier 43; J. C. Powys 6, 4 July 1950). While still in the US-where he spent more than twenty-five years as an itinerant lecturer-he was called to the witness stand to defend the editors of The Little Review, who were being sued for having published several episodes from Ulysses (1918-1920) and in particular "Nausicaa". J. C. Powys testified that James Joyce's novel was "too obscure and philosophical a work to be in any sense corrupting," of the time, who tended to consider that "obscurity implied obscenity" (Parkes 9). ${ }^{2}$

2 J. C. Powys was at first sight a rather unlikely defender and writer of obscenities. This is what he said about himself in a letter he wrote to Henry Miller in 1950:

Another difference between us is my old maidishness-It's a wonder I ever managed

to have a son \& it's natural enough he should be a Roman Catholic Priest-[...] [my 
vices] are vices that could easily exist in an extremely fastidious old maid who shivered at those three words of four letters \& of one syllable that our authorities ban the use of in your most widely known works! In fact I have all my life been actually that fastidious old maid [...]. (Peltier 34; J. C. Powys 3, 22 May 1950)

This "old maid" was outwardly squeamish; there are few dirty words-for instance "bitch" and "whore"-in A Glastonbury Romance, which is 1120 pages long, and they do sound rather unnatural under J. C. Powys's pen. His "old maidishness," however, was in no way conventional, even beyond the mere gender trouble implied by the feminized self-characterization. Indeed in the very same letter J. C. Powys also spoke of "[his] instinctive sex-vices [his] inherent sadism \& masochism \& spiritual \& mental homosexuality (which is a weird sort of twice inverted Lesbianism when I really examine it)" (Peltier 34; J. C. Powys 3, 22 May 1950). These traits lurk in the background of the first five novels J.C. Powys had written from 1915 to 1929 but came to the fore in A Glastonbury Romance, ${ }^{3}$ a novel published in 1932, one year before the lifting of the ban on Ulysses in America. The uncensored publication of Powys's novel is evidence of what Rachel Potter refers to as "the seemingly liberalization of rules on acceptable fiction" in the 1930s (Potter 2013b, 9), but there may also be more intrinsic reasons.

4 A Glastonbury Romance is an encyclopaedic collection of all the sexual activities that were rumoured at the time to corrupt "the minds and morals of those who are open to such immoral influences" (Benjamin Hicklin quoted in Potter 2013b, 2) and as a result to deprave families and communities. I will briefly refer to these elements in the first section of the article, where the word "obscene" will be used in a very broad sense, as was the case in the 1920s-a time when the highly "mobile category" of the obscene (Mullin 19) was tapped into to ban not only Ulysses (1923) but also The Well of Loneliness (1928), a novel which is far from racy. $21^{\text {st }}$-century readers will take all the sexual activities mentioned in A Glastonbury Romance in their stride but it could not have been the case in 1932 on account of the pervading sexual morality, which though laxer in the 1930s than in the 1920s, was not what it is today. I will try and consider why the novel was not deemed obscene and to do so I will draw on the distinction which can be established between "bawdiness" and "obscenity". While the first term implies humour and good humour, the second one seems to be more overwhelmingly associated with the idea of filth: "what is bad about obscene sexuality is that it portends ills because it is related in some way to matter that is base, putrid, unclean, and offensive to the senses" (Dillon 267).

Two passages will be studied in detail in the second section to probe into the category of the obscene. Admittedly, these two scenes are not related with sexuality proper. One of them is overtly scatological, a kind of indecency deemed obscene at the time: "the word 'obscene' referred to ideas about the limits of representation; to those aspects of humanity or language which ought to remain off stage" (Potter 2013a, 3). The other scene is about the sudden encounter with the dead carcass of a cat; strictly speaking this cannot be considered as obscene, especially as nobody has staged it on purpose. But obscenity has also come to be associated with what is low and 'informe'. In the 1950s J.C. Powys discussed pornography and obscenity with Henry Miller, with whom he corresponded until his death in 1963. They agreed that pornography, which they rejected for being merely a titillating thing, was widely different from obscenity, which they both praised. ${ }^{4}$ Henry Miller was to clarify his vision of obscenity later and I think J.C. Powys would have agreed with his words: 
When obscenity crops out in art, in literature particularly, it usually functions as a technical device: the element of the deliberate which is there has nothing to do with sexual excitation, as in pornography. If there is an ulterior motive at work, it is one which goes far beyond sex. Its purpose is to awaken, to usher in a sense of reality. (Miller quoted in G. Mayne 66)

In fact Henry Miller associated obscenity with "the most repulsive aspects of concrete matter: death, flesh, rottenness, excretions of the body" (Mayne, 67). This is precisely what is stake in the two passages under study, which deal with concrete matter, expose the protagonists and the readers to the lowest realities and stress their connection with the sacred. This will enable us to look at the affinities of the obscene with the abject from a Kristevan angle. ${ }^{5}$

In the third section the article focuses on the obscenity oozing from a character's whole frame of mind. The shift is in keeping not only with what Rachel Potter asserts about obscenity in the modernist period ("The obscene changed from something connected to the body-particularly the sexual and excremental-to the uncomfortable or unconscious dimensions of the psyche" [Potter 2013a, 10]) but also with Powys's idiosyncratic conception of obscenity. In this particular case, the sexual and the psyche are intrinsically linked and the role played by the attitude of the audience-a certain Mr. Evans-is in the foreground since he is the one experiencing a "fearful thrill" in seeing what is usually forbidden. ${ }^{6}$

\section{"To hell with middle-class pruderies" (GR 900)}

8 The sentence is tellingly pronounced by the old aristocrat of the novel, the Marquis of P. It could be used to sum up the novel as a whole since it may be read as a catalogue of the sexual activities and vices that were considered indecent at the time.

In the novel extramarital sex is more than common. Persephone Spear goes from her husband to her uncle, to another woman and then to Will Zoyland before jilting them all one after another with "a clever modernity" (GR 237) that knows no limits. As for Will Zoyland, he is ready to share his wife, Nell, with Sam Dekker, provided she does not forbid him to sleep with her. He openly says so to her lover:

If Nell will stop this foolery of sleeping on the sitting-room sofa, will stop, in fact this foolery of being cross with me and cold to me, I'll be ready-d'ye hear me lad? -I'll be ready to share her with ye. So long as ye don't tumble her 'in me wone bed,' as they say around here, ye can have the lass up hill and down dale-I'm mum. I'm mute. (GR 133)

10 What is more Sam Dekker is the son of the vicar, who is present during the conversation and who will eventually fall in love with his son's mistress (or rather with her "white limbs" [GR 246] and breasts) and project "his own feelings into those of his son's behaviour" (GR 287). In a certain way Nell's body could be said to be exchanged, reminding the reader of the idea that "men establish bonds with each other through the exchange of a female body" (Parkes 41).

11 Secondly, although there are quite a few illegitimate children in the novel-Will Zoyland is one of them and he is the son of the Marquis of P.-non-reproductive sexuality is everywhere to be found. The old aristocrat of the novel is more than happy to let his daughter have a fling without getting married and asks her and her lover if they know about contraceptive devices (“'You understand how to keep-you mustn't be 
cross at an old man's grossness-from getting-into trouble, as the servants say?' Rachel nodded mischievously [...]" [GR 898]). John Crow and his cousin Mary are in love but their sexuality seems to be of a complex kind and may not entail penetration, which could be one way of understanding why the narrator calls it "sterile" (GR 312) and could cast light on John's own questioning: "Was that because he was congenitally more attracted to men than women? 'Is the way I make love to Mary,' he thought, 'a sign that I am all the time half thinking of her as a boy?"' (GR 491)

In fact, and in some cases this clearly has something to do with the idea of sterility, most of the male characters in the novels but also some women seem to have experienced some kind of homosexual desires at one time or another, and to have indulged in them. Bisexuality lurks in the background. Philip Crow, the capitalist, remembers a passionate love affair he had "with a boy at school" (GR 671). Miss Drew is passionately in love with Mary Crow (GR 228); she vents out her emotions in a passionate outburst and her lesbian longings are explicit both physically or verbally (GR 636-640). So are those of Angela Beere lying next to Persephone Spear (GR 698). As for John Crow, he recalls fumbling with Tom Barter and is still aroused by the memory of their "vicious play that hot Sunday afternoon at the bottom of the boat":

[...] and John was surprised at himself, glancing furtively at Tom's stolid profile, to find what an intense thrill it still gave him, what a delicious voluptuous sensation, to feel himself weak and soft, where Tom was strong and hard! (GR 264)

These are only a few instances of the countless hints at lechery and indecencies where the swapping of gender roles, incestuous tendencies, sterile sexuality and prostitution take pride of place.

The omnipresence of sexual transgression is also obvious in that the most spiritual moments in the novel are imbued with eroticism, even though this may have more to do with blasphemy than obscenity. As when Mary Crow's moment of being in front of the rising sun is conveyed in explicitly orgasmic terms:

Her soul had come back with a violent spasm, like a rush of blood to her head, and her whole nature seemed to pour itself out towards the reddish light on that tall column. Her pulse of happiness was intense. What she experienced was like a quivering love ecstasy that had no human object. She could actually feel the small round breasts under her nightgown shiver and distend. Her head instinctively fell back a little, while her chin was lifted up. Her lips parted, and a smile that was a smile of indescribable happiness flickered over her face. (GR 556)

Even Leonardo da Vinci's paintings are reinterpreted in this atmosphere infused with desire and sexuality by a narrator whose thoughts would have left E. M. Forster's Cecil Vyse aghast in A Room with a View:

[...] and to Leonardo the wavering beginning of a girl's smile carried, folded within its calyx, the blue veins of her thighs, the wild-rose tips of her nipples, the arch of her instep, the silkiness of her flanks, the unfathomable recessions of her final yielding to the pressure of desire. (GR 981-982)

And yet A Glastonbury Romance was not censored. This may have a lot to do with the fact that sexuality is hardly ever presented as "permeated with filth" (Dillon 269). As a result and even if, as we shall see, it is not always devoid of perversities, on the whole it appears to be more bawdy than obscene. To draw this distinction one may use Martin Dillon's definition of obscenity as opposed to bawdiness in his analysis of Sade's The 120 Days. He examines the specificities of obscenity and suggests that Sade's The 120 Days "is, paradigmatically, an obscene work" precisely on this account: 
The 120 Days is, paradigmatically, an obscene work. It invites us into an obscene world. It does that by taking something worldly-a kiss in particular, sexuality in general-and presenting it as obscene, i.e., as essentially permeated with filth and associated with decay and death. (Dillon 269)

Such is clearly not the case in J.C. Powys's novel. In fact the down-to-earth, even matter-of-fact way of referring to all sorts of sexuality seems to suggest that in spite of "middle-class pruderies" these things have always existed and will continue to exist and that there is something rather healthy and life-affirming about such attitudes in human beings who are simply "personalised animals". Does Will Zoyland not claim that all this is "natural" for girls as well as for boys (GR 133)? Does the vicar himself not have "a very natural and earthly attitude towards erotic emotion" (GR 284)? Sexuality, whatever its guise, is not so much flaunted as shown as one of the realities of life ("natural").

Now in J.C. Powys's words, reality lies "between the urinal and the stars"; he lets his imagination run the whole gamut. His tone, however, is neither prophetic nor polemical, even when he refers to homoerotic love. Homoerotic images and scenes abound in his novel and in some cases they are far racier than in The Well of Loneliness banned after an obscenity trial four years before the publication of A Glastonbury Romance. Powys's novel may not have been banned because the tone is far less solemn and much more humorous and Rabelaisian than in Radclyffe Hall's novel (Parkes 148-160). ${ }^{7}$

The ostensible indifference of transgressive characters to the social and in some cases religious norms they are transgressing is in keeping with the fifth gospel developed by John Geard, the very Rabelaisian mayor of the town, who lives life to the full and indulges in the impulses of his grotesque body: among other things he enjoys making water in his garden and breaking wind. Angelika Reichmann compares his one-year reign to "the ephemeral power of the Carnival King-in fact, a fool" (Reichmann 2010, 75). Although John Geard hardly ever expatiates on this fifth gospel of his, he seems to adumbrate the sanctity of all kinds of love if the heart is pure: "Only good can come from every embrace. It matters not at all from what cups, or from what goblets, we drink, so long as without being cruel, we drink up Life' (GR 1085). "To hell with middleclass pruderies" indeed; to hell with the social hierarchies and the censorship that have accompanied them.

There is in fact only one form of obscenity left: it is hinted at in the previous sentence through the word "cruel" but is also everywhere to be found in the novel, embedded as it is in the living world (GR 643,658,691,930), which is more often than not "red in tooth and claw" "under the pressure of the cruelty of the First Cause" (GR 930): such obscenity as there is, is that of acute mental or physical suffering, the latter being precisely what two characters, John Crow and Sam Dekker, have to stare at in horror.

\section{"Obscenity may revolt, disgust and instruct, but does not excite" (Sade quoted by Henry Miller in Peltier 38; Henry Miller 5, 6 June 1950)}

As already said, obscenity is hardly a concept; it is an elusive and relative category. One way of approaching it is to analyse the effects it has on those who are confronted with 
it as Henry Miller does when he uses the words "revolt" and "disgust" in a letter to Powys:

I have been reading about the life and work of de Sade. He understood clearly the difference between pornography and obscenity. Says de Sade (in Aline et Valcour): -“Obscenity may revolt, disgust and instruct, but does not excite." (Peltier 38; H. Miller 5, 6 June 1950)

This is what I will now analyse in two episodes when the protagonists come up against the obscene imposing itself on them and "usher[ing] a sense of reality", which, if one follows Julia Kristeva's argument in Pouvoir de l'horreur has something to do with what is likely to threaten the individual's sense of the self as opposed to an originally abjected other. ${ }^{9}$

23 John Crow is an atheist who loathes superstition and feels ill at ease in the atmosphere of Glastonbury, which is soaked in legends. Although John's secret wish is to play havoc, he nonetheless goes to great lengths to stage a Midsummer pageant for the Mayor, who wants Glastonbury to become a New Jerusalem. He once finds himself crossing the River Brue at Pomparles Bridge, the very place where King Arthur is supposed to have thrown his sword Excalibur. He ends up staring at something which he had not expected:

John's eyes, roaming in search of anything that might recover the ambiguous romance that hung about the spot, fell eventually upon a dead cat whose distended belly, almost devoid of fur, presented itself, together with two paws and a shapeless head that was one desperate grin of despair, to the mockery of the sunshine. (GR 357; emphasis mine)

This first description is followed by several other mentions in the course of four pages: "this encounter with the distorted face and up-blown belly of this poor corpse" (GR 357); "that hairless belly in the mud," "the despairing grin of that scarcely recognisable head" (GR 358); "the mindless despair of that decomposed cat-head in the filthy Brue-mud" (358); "the abominable despair in the hollow-sockets of that decomposed cathead" (GR 360); "Its swollen hairless belly ... its paws that resemble the claws of a bird ... the snarling ecstasy of its curse" (GR 360; emphasis mine). John is faced with the refuse out of a garbage can coming from Glastonbury (GR 360), in other words with the physical presence of death, and the confrontation is inadmissible to his narcissistic self because the shapeless head of the cat holds up a mirror to his own face. It can be argued that the sudden intrusion of the abject is so accidental that the word "obscenity" is hardly relevant in so far as this was not intended for him (Maier 2-3); nevertheless John's fascination in the passage transforms decaying matter into something obscene. The narrator himself uses the word once in the passage: "In all normal suffering there are certain natural laws such as mitigate what the entity in question is enduring. When these laws are broken an element enters that is monstrous, bestial, obscene." (GR 360; emphasis mine) The last sentence of the quotation also implies that the obscene is associated with the idea of the disruption of a certain order ("when these laws are broken"), a fact proved by the state of decomposition of the dead cat, whose head has lost its form ("shapeless", "distorted"). Now, what has no form, "what reduces the logos to silence" is obscene (Mayne 64). ${ }^{10}$

As for Sam Dekker, he has decided to break up with his mistress and to embark on a mystical quest of his own during which he tries to behave like a saint, imitating some of the Christian knights of medieval romances. In the passage under study he is about to give an enema to an old man, whose anus is affected by piles, and finally gives it: 
"bending over the old gentleman's rear", "the anus of an aged man" (GR 948). Sam is thus face to face so to speak with the materiality of the body and its excremental functions all the more so as he is also in charge of getting rid of what is in the chamber pot: "'I'll carry this away"' (GR 949); "he emptied the thing in the privy." (GR 949)

In both cases the protagonists have to deal with the "aching body" the destiny of which is to die: John is looking at a corpse; the old man whom Sam is tending refers to his own carcass ("'and I be a wambly carcass"' [GR 948]). Now it seems to me the two passages revolving around a confrontation with abject material have a lot in common.

First of all, the only sense that is explicitly involved is the sense of sight although there could have been another one in the case of Sam. John is visually fascinated with the dead cat and its grin: "John's eyes" (GR 357); "stare" (GR 358); "John stared down" (GR 360). In spite of his repulsion he cannot look away almost as if he was mesmerized. As for Sam, even before starting, he "had visualised every detail of the giving of the enema" (GR 946); "these piles, [...], presented themselves to his mind" (GR 947). The visual is probably what is paramount as far as the obscene is concerned and in Sam's case it is interesting to see that the effect of repugnance is anticipated and exists by a projection of the imagination.

Secondly, the same words are repeated several times (in particular in the episode concerning John) testifying to the protagonist's unwitting fascination; they also function as a snare in which the reader could be trapped. The mention of the repellent details is obsessive and nothing is done to redeem them: the hairless and swollen belly (which on account of its being hairless reminds one of a human belly), the squashed head and its sinister grin. The language used is descriptive and denotative on the whole, with the exception of the lexical field of despair. What is suggested is that these things present themselves as is made clear in the text the first time John sees the cat and the first time the piles are mentioned: "presented itself" (GR 357); "these piles, [...], presented themselves to his mind" (GR 947). ${ }^{11}$

Thirdly, the reaction of the two protagonists is a physical one. The narrator speaks of John's "diabolical twinge of mental and even of physical misery" (GR 357) and then John starts to grin back at the cat. The narrator leaves no doubt that Sam's reaction is above all a bodily one: "his body weakly murmured" (GR 947); "his cowardly body was still trying to escape" (GR 947). Both protagonists experience "revolt and disgust". Now, as indicated by Maddelena Mazzocut-Mis,

In disgust the link with corporeity is immediate. On the one hand, the body is an object of disgust, body putrefied, body contaminated. On the other hand, one's reaction to disgust is corporeal, visceral, physiological. (Mazzocut-Mis 108)

The two protagonists react as embodied characters and the distance between themselves and what they are staring at or imagining disappears. No wonder John's grin is a mirror-like image of the cat's: "he replied to the despairing grin of that scarcely recognisable head with a grin of his own that was no less unredeemed" (GR 358).

31 Fourthly, there is a moment when both protagonists seem to have lost the power to express themselves in words: John is said to be "dazed" ("a dazed condition of his senses" [GR 360]) confronted as he is not only with death but also with the suffering he associates with death and the "torturing world" (GR 360) and with the meaninglessness of "earth-life" (GR 358). No words are exchanged between the old man and Sam during the procedure. Probably because, as suggested by Henry Miller, "a sense of reality" has 
been ushered in in a way which leaves the two protagonists speechless. In both scenes John and Sam are face to face with the crumbling distinction between subject and object, which takes them back to a pre-symbolic relation with the world.

The propinquity of the obscene and the sacred in these two passages ${ }^{12}$ gives us indirect insight into the obscene as an experience of disintegrating limits between self and notself. Having gazed at the dead cat for a very long time, John, who as I have said is no believer, is given a vision:

John was struck, there, leaning as he was against the sun-warmed parapet, by a sudden rending and blinding shock [...] He distinctively saw ... literally shearing the sun-lit air with a whiteness like milk, [...], an object, resembling a sword, falling into the mud of the river! (GR 361)

Now, the obscene is what cannot be redeemed by the Symbolic ("he replied to the despairing grin of that scarcely recognisable head with a grin of his own that was no less unredeemed." [GR 358]; emphasis mine). Sylvain Floc'h writes that:

L'obscène, c'est l'imbouffable, l'inconsommable, la répugnante confrontation avec un corps qui refuse de se laisser convertir en hostie et inflige sa lourde présence. La bête crevée refuse de se laisser transformer en planche de salut, et l'esprit se retrouve confronté à sa propre obscénité [...] L'objet résiste à l'extradition, s'obstine à coïncider avec lui-même, avec son apparence, et, avec un manque de tact absolu, s'installe dans le littéral au grand mépris du métaphorique." (Floc'h 12)

But is it possible to stare at it without making up for it? Is it possible, to quote Henry Miller, to let "a sense of reality" sink in without begetting some "mystical" and / or "aesthetic" discourse? The answer is probably "no"; at least this is what Julia Kristeva contends. Could it be then that John's confrontation with the obscene and with the world as it is when it is stripped of all illusions and his realization of his own proximity with the abject is so overwhelming that he cannot but sublimate it although he is an unlikely candidate for such a task? Could his vision be simply a way of hinting at what one's mind tends to do, namely to produce "mystical" or "aesthetic" discourse on shapeless matter, when one has to deal with the abject? In that respect and keeping Julia Kristeva's analysis in mind, it is interesting to note that the object which John identifies as Arthur's sword is a phallic symbol for the law of the father, which could cut off what has to be got rid of. The disappearance of the sword in the mud, however, is ambiguous to say the least, especially as the sword leaves no trace whatsoever behind ("When it struck the mud it disappeared."[GR 361]). Could this mean that there is nothing left to redeem concrete matter, whose very nature is embedded in the Bruemud (GR 360), and that the vision is only temporary? The proliferation of meanings is after all one of the consequences of the confrontation with the obscene since the obscene stresses the vulnerability of the symbolic. Now this very proliferation was also at the heart of modernist literature.

The interpretation suggesting there is nothing left to redeem the world is plausible if we think of what happens to Sam. The day before giving the enema to the old man, Sam is rewarded in his quest since he sees the Grail (GR 938-9):

What he saw was at first accompanied by a crashing pain. That was the word Sam himself thought of to express it-the word crashing. But as his vision clarified before him and grew distinct this pain died away. But it was dazzling, hurting, blinding, at first, and it was associated in his mind with the sense of a sharp, long-shaped thing piercing his guts. [...] what he felt was a gigantic spear was struck into his bowels and struck from below. (GR 938-939). 
enough the vision seems to foreshadow the enema. Sam himself conflates these two opposite moments of his life in a blasphemous way and the sacred finds itself on the same level as the obscene: "The two extremes of his experience, the anus of an aged man and the wavering shaft of an Absolute piercing, mingled and fused together in his consciousness." (GR 948) "Holy Sam" 's taking care of the old man while thinking of the Holy Grail smacks of the scatological streak in medieval literature, which would be in keeping with Geard's fifth gospel (especially as the scene is also humorous); it may also be a modern reminder of the specificity of the New Testament since Christ comes into contact with those who are not pure. ${ }^{13}$ This may also mean that the dualism Sam has based his holy quest on (the body versus the spirit; the material versus the divine) will come to naught in the end and as such this confrontation with obscenity does "instruct" the young man. Sam is cleansed of his dualism (as the old man is cleansed of his excrement) as if some kind of catharsis had taken place-which according to Henry Miller is precisely the role of obscenity. ${ }^{14}$ Does Sam not discard his own asceticism and question the idea of the Resurrection as a result? ("A sharp pang took him when-in this extremity of clairvoyance-he realised that his living tortured Christ was now changed to something else" [GR 948]). ${ }^{15}$

Thus the aching body is caught in a nexus of abjection and religion. Sam's vision takes place before he gives the enema to the old man whereas John's occurs after he looked at the carcass of the cat. The chronological order may be inverted but the closeness between the sacred and the abject is underlined as if they were two sides of the same coin. The reader is likely to consider whether the sacred is not the answer to the abject when the "sense of reality" is too overwhelming-an answer which is both vain and necessary-and whether the realities of life are not here to belie man's aspirations to spirituality when they are based on dualism.

\section{"Nothing is in itself obscene apart from the human observer" (Havelock Ellis quoted in Parkes 83)}

The last case I would like to examine is that of Mr Evans, who has to deal with an obscenity which is not exterior to him but comes from within, from his psyche. ${ }^{16}$ This time we are dealing not with an accidental symptom of disturbance but with a more general structure, which organizes the whole life of Mr Evans, a character whose sadomasochistic desires and fascination with some images (GR 109) may well be "substitutions for repressed childhood or elementary experiences." (Potter 2013a, 7) ${ }^{17}$

Early in the narrative we are told that something is amiss in the life of this man, who is tormented with sadistic visions, in particular the vision of "a killing blow delivered by an iron bar." (GR 150, 252) That such images can be considered "obscene" is to be related to what J.C. Powys's own vision of real obscenity, namely acute mental or physical suffering and their link with cruelty.

They were scenes of sadistic cruelty, these pictures that dwelt in the back chambers of Mr. Evans' mind; and the extraordinary thing about them was that, in spite of their iniquity, which was indeed abominable, they still produce in him-whenever the least glimpse of them took form again-an inebriation of erotic excitement that made his pulses beat, his blood dance, his senses swoon, his knees knock together. The taste of the least of these loathsome scenes was so overpowering to him that it reduced all the rest of life-eating, drinking, working, playing, walking, talking-to 
tedious occurrences, that had to be got through but that were wanting entirely in the electric quiver of real excitement. [...] No one would ever know-unless Mr Evans confessed to a priest-how many of these abominations had actually been practised, how many of them described in forbidden books, or how many just simply invented by a perverted imagination." (GR 109)

r. Evans is a scholar in charge of an antiquarian shop, in the cellar of which there is a book, entitled The Unpardonable Sin, which turns out to be "some monstrous Aphrodisiac of Obscenities" (GR 247), attracting and repelling him at the same time. Throughout the novel Mr Evans does what he cannot to think too much of the book or to go near it, so guilt-ridden he feels about his own sadistic feelings. He is nevertheless haunted by some images. After overcoming his vices for a while thanks to his marriage he yields to temptation and is at a loss to fight back against the return of the repressed when he is given the opportunity of becoming an actual voyeur and of watching somebody kill a victim with an iron bar (Reichmann 2012, 32).

41

whection is extreme as made clear previously (GR 109): "His legs were shaking. His knees were knocking together! His fingers must have been shaking too..." (GR 245); "His hands shook so much and his knees knocked together so violently, as he gloated over this dreadful scene, [...]" (GR 1003). As indicated by the aforementioned "an inebriation of erotic excitement" (GR 109) or "some monstrous Aphrodisiac of Obscenities" (GR 247) Mr Evans's reaction is an erotic one. The more obsessed he is, the more recurrent the metaphor of the "worm-snake" of the "sex nerve" becomes until an erection and an orgasm are suggested by a description of the rest of his body (GR 1003) and a deceptively demure remark: "That little coiled-up nerve-snake, now suddenly grown so quiescent that if Mr Evans were to strip himself naked there would have been nothing indecent in the exposure [...]" (GR 1004).

The obscenity is connected with the subject's psyche and Mr Evans's misery throughout the story is due to his being "the slave of his conscience". He tries to make amends for his sinful fantasies but does so in an ambiguous masochistic way as when he decides to play the role of Christ on the Cross during the pageant and suffers so acutely that he faints after having had an orgasm and after some of his blood vessels have burst. His sadistic desires, however, remain where they are, in his subterranean psyche, in the same way as The Unpardonable Sin is locked in a bookcase in the dark recesses of the cellar ("a still narrower staircase going down" (GR 244); "that dark little staircase"; "the cellar", "a key-hole in this glass-door" [GR 245]). The narrator proffers an obscene explanation for this obsession which may be Freudian: "-and it is quite possible that the whole thing started from his father's forcing his mother to let him enjoy her long after the child's conception had begun-" (GR 1020).

Now beyond the combination of obscenity and religion ("the holy excess of sadistic satisfaction" [GR 1004]) and the "immensely powerful scene of auto-erotic flagellation" on the cross (Krissdottir 260), Mr Evans's position is all the more interesting as his sadistic desires do pre-exist books but are fuelled by them since the scenes that torment him have been written on purpose (which is, according to Corinne Maier, the necessary condition for the idea of obscenity): ${ }^{18}$

Once, when he was very young and seized by a sadistic frenzy-[...]-he had killed something with a piece of iron. After that the little Owen would frantically turn over the pages of all his children's books to find pictures of creatures being killed, especially being killed by heavily crushing instruments. It had to be a thing of iron 
and it had to come crashing down, smashing everything, smashing skull and vertebrae together, or the performance, demanded with such a swooning, trembling, fainting orgasm by the worm-snake, would not be a master one! (GR 1020) the books he has read into "pictures [dwelling] in the dark chambers of [his] mind" (GR 109). Now, when these "palpable images" (GR 108) resurface they trigger off his bodily excitement, an idea foreshadowed by the adjective "palpable": the distance between Mr Evans and the object he is looking at tends to disappear. He is nevertheless in the position of the voyeur gazing at what is for him a sexualised object-a phallic iron bar (GR 1020-1021)-which has been staged probably on purpose in some "forbidden book" (GR 109). And he will be geared into action, and will plan to actually witness in the real world what he has been reading about in the fictional one, the signified replacing the signifier in the end (GR 986-1062).

Is Mr Evans as a result in the position of the "mediating voyeur figure whose own excitement in gazing at the sexual object is intended to function as a model to viewers" (Pease 131-132)? It is not for me to say since obscene qualities reside both in object and subject (Dillon 260). But as far as J. C. Powys himself was concerned Mr Evans was certainly that kind of figure: "It must be that the idea of 'voyeurs' getting such wicked pleasures in itself stirs up my evil being even though the violence itself is totally out of my sphere!" (quoted in Krissdottir 259) ${ }^{19}$ It seems to me, however, that if in these scenes one becomes a voyeur it may partly be on account of the rhetoric of extreme effects concerning Evans's un-aesthetic bodily reaction. Thus willy-nilly we are reminded of "the physically stimulating powers of books" (Pease 100), even if only vicariously, and made to question our own attitude as readers of obscenities staged on purpose by some narrator.

A Glastonbury Romance is "an enormous book, not just in size but in scope" (Krissdottir 262) and obscenity is simply one theme amongst many others and appears in different guises. Sexual transgressions, which could have been seen as obscene at the time, are multifarious and at the same time seem very natural. At times J.C. Powys takes a more psychoanalytical stance so as to deal with the affinities between the obscene, the abject and the sacred. And he also prompts the reader to ponder over the role of the observer in the constitution of the obscene as such, tackling a subject he himself was particularly responsive to.

\section{BIBLIOGRAPHY}

Anderson, Margaret C. “'Ulysses' in Court.” The Little Review (Jan-Mar. 1921): 21-5. Last accessed on November 10, 2018. <http://library.brown.edu/pdfs/1299778513171878.pdf>.

Bradshaw, David \& Rachel Potter. Prudes on the Prowl: Fiction and Obscenity in England, 1850 to the Present Day. Oxford: Oxford UP, 2013. 
Dillon, Martin. "The Phenomenon of Obscenity in Literature: The Specification of a Value." Journal of Value Inquiry 16:4 (1982): 259-274.

Fawkner H. F. "Dysfunctional Responsiveness in A Glastonbury Romance: J.C.P, Nihilism and Christianity.” Powys Review XIV (2004): 103-120.

Floc'h, Sylvain. "L'obscène et le révoltant." In L'Obscène. Cahiers de l'université. UPPA, 1984. 5-16.

Forster, Hal. “Obscene, Abject, Traumatic.” October 78 (Fall 1996): 107-124.

Krissdottir, Morine. The Life of John Cowper Powys: Descents of Memory. New York: Overlook Duckworth, 2007

Kristeva, Julia. Pouvoirs de l'horreur. 1980. Paris: Seuil, 1983.

Lawrence, D. H. "Introduction to the Unexpurgated Edition of Pansies (1929)." In The Complete Poems of D.H. Lawrence. Ware: Wordsworth Editions, 2004. 624-627.

Maier, Corinne. "Dynamite de l'obscène et le hic de la perversion." Revue Silène. (2006). Last accessed on October 20, 2018. <http://www.revue-silene.comf/index.php?sp=liv\&livre_id=50>.

Mazzocut-Mis, Maddalena. How Far can We Go? Pain, Excess and the Obscene. J. Coggan trans. Cambridge: Cambridge Scholars Publishing, 2012.

Mayne, Gilles. Eroticism in G. Bataille and Henry Miller. Birmingham: Summa Publications, 1993.

Mullin, Katherine. "Poison More Deadly than Prussic Acid: Defining Obscenity After the 1857 Obscenity Act 1857-1885." In Prudes on the Prowl: Fiction and Obscenity in England, 1850 to the Present Day. Eds. David Bradshaw \& Rachel Potter. Oxford: Oxford UP, 2013. 11-29.

Parkes, Adam. Modernism and the Theater of Censorship. New York \& Oxford: Oxford UP, 1996.

Pease, Allison. Modernism, Mass-Culture and the Aesthetics of Obscenity. Cambridge: Cambridge UP, 2000.

Peltier, Jacqueline (ed.). Proteus and the Magician: The Letters of Henry Miller and John Cowper Powys. Mappowder: The Powys Press, 2014.

Potter, Rachel. Obscene Modernism: Literary Censorship and Experiment 1900-1940. Oxford: Oxford UP, 2013.

---. "Introduction." In Prudes on the Prowl: Fiction and Obscenity in England, 1850 to the Present Day. Eds. David Bradshaw \& Rachel Potter. Oxford: Oxford UP, 2013. 2-10.

---. Censorship and Sovereignty (1916-1929)." In Prudes on the Prowl: Fiction and Obscenity in England, 1850 to the Present Day. Eds. David Bradshaw \& Rachel Potter. Oxford: Oxford UP, 2013. 71-89.

Powys, John Cowper. A Glastonbury Romance. 1932. New York: The Overlook Press, 1996.

Reichmann, Angelika. “'Pure Romance': Narcissus in the Town of Mirrors.” Powys Review XXII (2012): 21-32.

---. "Dostoevsky in Wessex: John Cowper Powys after Bakhtin and Kristeva." Powys Review XX (2010): 27-48.

Walker Read, Allan. “An obscenity symbol.” American Speech 9: 4 (1934): 264-278. 


\section{NOTES}

1. "Mr. John Cowper Powys testifies that 'Ulysses' is too obscure and philosophical a work to be in any sense corrupting. (I wonder, as Mr. Powys takes the stand, whether his look and talk convey to the court that his mind is in the habit of functioning in regions where theirs could not penetrate: and I imagine the judges saying: 'This man obviously knows much more about the matter than we do-the case is dismissed.' Of course I have no historical basis for expecting such a thing. I believe it has never happened" (Anderson 23).

2. J.C. Powys's remark was precisely to the point in so far as the form used in Ulysses invalidates its sensuous content: "the sensuous content in Ulysses's narrative is rendered impotent by form" (Pease 90).

3. Although anchored in the political turmoil of the 1920s, A Glastonbury should be read above all as a modern re-writing of the Grail legends. It focuses on the life of a rural community and boasts about fifty principal characters, whose lives it follows over the span of one year.

4. "[I] agree with you in praising the obscene \& denouncing the pornographical ..." (Peltier 36; J.C. Powys 4, 29 May 1950).

5. "[J. Kristeva] also developed a theory about a rather different category of the literary obscene. For her there is a genre of twentieth century 'abject' literature, which 'takes up where apocalypse and carnival left off."' (Potter 2013a, 9) Kristeva's definition of the abject revolves around the idea that it "is what I must get rid of in order to be an I at all. It is a phantasmatic substance not only alien to the subject but intimate with it-too much so in fact, and this overproximity produces panic in the subject. In this way the abject touches on the fragility of our boundaries, of the spatial distinction between our insides and outsides as well as the temporal passage between the maternal body and the paternal law. Both spatially and temporally, then, abjection is a condition in which subject-hood is troubled, 'where meaning collapses'; hence its attraction for avant-garde artists and writers who want to disturb these orderings of subject and society" (Forster 114).

6. I am here referring to Allan Walker Read's old definition of obscenity in 1934: "To hazard a definition, we may say that obscenity is any reference to the bodily functions [sex, the excrementary functions] that gives to anyone a certain emotional reaction, that of a certain 'fearful thrill' in seeing, doing, or speaking the forbidden" (Walker Read 264).

7. J. C. Powys was also the author on a book on Rabelais in 1948.

8. Alfred Lord Tennyson's In Memoriam A. H. H., 1849. The quotation is in Canto 56 and refers to man: "Who trusted God was love indeed / And love Creation's final law/Tho' Nature, red in tooth and claw/With ravine, shriek'd against his creed"

Tennyson, Alfred, "In Memoriam", LVI, last accessed on June 5, $2019<\mathrm{https}$ ://www.onlineliterature.com/tennyson/718>.

9. “L'excrément et ses équivalents (pourriture, infection, maladie, cadavre, etc.) représentent le danger venu de l'extérieur de l'identité: le moi menacé par du non-moi, la société menacée par son dehors, la vie par la mort" (Kristeva 86).

10. “Toute cette désorganisation de l'organique traduit la mort violente d'un ordre par ailleurs menace de mort lente. [...] Selon cette perspective, l'obscénité, c'est l'innommable, l'indifférencié, le non-identifiable" (Floc'h 10).

11. Henry Miller too spoke of "these grinning, leering, skulking skulls" behind [his] words. (quoted in G. Mayne 66). The cat's grin also calls to mind some of the pictures by Francis Bacon.

12. While writing A Glastonbury Romance, J.C. Powys was reading Gustav Fechner and "Fechner's theories on the nature of the relation between the spiritual and material world may have influenced the Romance" (Krissdottir 258). 
13. "C'est par l'abolition des tabous alimentaires, par la consommation avec les païens, par le contact verbal et gestuel avec les lépreux [...] que se distingue [...] le message du Christ" (Kristeva 135).

14. "By forcing us to stare obscenity in the face, Miller's fiction seems to prepare us for an ecstatic experience reaching the level of intensity of a "catharsis"' (Mayne 67).

15. Without any reference to the obscene, H. F. Fawkner drew the same conclusion when he wrote: "No distinction is in the last analysis made between matter understood from the viewpoint of Christ and matter understood from the viewpoint of nature, between natural flesh and flesh that no longer belongs to nature, between natural and non-natural suffering" (Fawkner 107).

16. This is in keeping with what Julia Kristeva said about the new, internalized vision of abjection developed in the New Testament: "L'idée d'une intériorisation subjective de l'abjection sera, elle, l'œuvre du Nouveau testament" (Kristeva 125).

17. Rachel Potter is here referring to Bataille's interpretation of obscene images in The Story of the Eye (1928).

18. "Aussi un fait pur, un événement, ne peut pas être intrinsèquement obscène : il ne le devient que s'il est pris dans les rets du filet d'un faiseur d'images ou d'un montreur de spectacles. L'obscène s'adresse au spectateur, il vient le déstabiliser, le refendre" (Maier 2-3).

19. See the following extract from one of his letters to Henry Miller: "I used to borrow from a friend Sadistic Books in French [...] and carry them off to my / lodging where I wd. read them with my knees knocking together \& all my pulses going it like mad in a prolonged cerebral fury of crazy unsatisfied satisfaction" (Peltier 40-1; J. C. Powys 5 [24 June 1950]).

\section{ABSTRACTS}

A Glastonbury Romance by John Cowper Powys was published in 1932, just one year before the ban on James Joyce's Ulysses was lifted in the United States. Powys's novel was not censored, although it is rich in scenes and hints that would have been deemed obscene in the United Kingdom barely ten years before. This is probably due to the evolving mores of society in the 1930s but this is also a consequence of the tone used by Powys, which will enable me to draw a distinction between bawdiness and obscenity. Then the detailed analysis of two passages in which the abject and the sacred vie with each other will make it possible to highlight some characteristics of the staging of the obscene: scopic drives, a pre-symbolic relation with the world and a confrontation with a sense of reality that is so overwhelming that the sacred appears as the only answer-an answer which is both vain and necessary. Lastly, the article offers to probe into the position of the implied reader of obscene works thanks to the mise en abyme that can be found in the novel.

Publié en 1932, un an avant que la censure dont l'Ulysses de James Joyce faisait l'objet aux ÉtatsUnis ne soit levée, le roman de John Cowper Powys, A Glastonbury Romance (1932), ne connut pas de démêlés avec la justice pour atteinte aux bonnes mœurs. Pourtant, il abonde en scènes et allusions qui auraient été jugées obscènes dix ans auparavant au Royaume-Uni. Si on peut voir dans cette absence de censure un effet de la libéralisation des mœurs dans les années 1930, on peut aussi penser qu'elle est la conséquence du ton utilisé par Powys, ce qui nous amènera dans un premier temps à distinguer paillardise et obscénité. Par la suite, l'analyse en détail de deux scènes où l'abject le dispute au sacré permettra d'étudier certains traits propres à la mise en 
scène de l'obscène : pulsion scopique, rapport pré-symbolique au monde, confrontation avec une réalité telle que le sacré apparaît comme la seule réponse à la fois vaine et indispensable. Enfin dans un troisième temps sera abordé le thème de la réception des œuvres obscènes et de leurs effets sur le lecteur, tel qu'il est mis en abyme dans le roman de Powys.

INDEX

Keywords: corpse, disorder, excrement, fascination, obscenity, bawdiness, perversion, sacred, sadism, sexuality

Mots-clés: cadavre, désordre, excrément, fascination, obscénité, paillardise, perversion, sacré, sadisme, sexualité

\section{AUTHORS}

\section{FLORENCE MARIE}

Maîtresse de conférences

Université de Pau

florence.marie@univ-pau.fr 